\title{
急勾配リーフ上のサンゴ礁州島形成・維持過程の研究
}

\section{Study on Formation M echanism and M aintenance Process of Coral cays on a Steep Slope Reef}

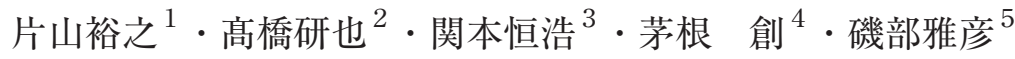 \\ Hiroyuki KATAYA M A, KenyaTA KA HA SHI, Tsunehiro SEK IM OTO \\ Hajime KAYANNE and Masahiko ISOBE
}

\begin{abstract}
Coral cays may be formed by the high waves in about several days. If the initial formation mechanism of coral cays can be understood, it will be useful for protection, the environmental preservation, and use of the coral reef seashore. M oreover, it can contribute also to protection of islands in Japan and the Pacific Ocean archipelagic country where the sea level rise due to global warming may result in submersion. In this paper, 3-dimensional hydraulic movable bed model tests were conducted to clarify the coral cays formation and maintenance process. Consequently, it turned out that wave breaking at leaf edge, the relative relation between leaf size and wavelength, and the cover effect of the wave and current by formation of the coral cays are important for the coral cays formation and maintenance process.
\end{abstract}

\section{1はじめに}

サンゴ礁州島とは，サンゴ礁上に波・流れによりサン ゴ砂等が堆積して形成される標高数mの低平な島である. サンゴ礁州島はインド洋や太平洋島嶼国で多く見られ, その数は200以上にも及ぶ. その形成・維持機構の解明 は, 我が国島嶼部だけに留まらず温暖化により水没が危 惧されている太平洋島嶼国の国土保全にも役立てると考 えられる(岩塚ら, 2012).

サンゴ礁州島は, 高波浪により短期間に形成, 消失さ れうることが既往の研究から明らかとなっている（例え ば, 宇多（1988）や鈴木（2013））。また鈴木ら（2013） は，サンゴ礁州島として西表島北方のバラス島の地形変 化を調査し, ある程度の規模の台風が来襲する度に島の 形状や高さの変化を伴う地形変化が生じていることを測 量を実施して確認している.

サンゴ礁州島の形成機構については, 過去に宇多ら (1990，1992，1995)，高橋ら（2011）が2次元水槽を用 いた水理模型実験により検討をしている。また岩塚ら （2012）は3次元水槽を用いた水理模型実験により波・流 れの影響によるサンゴ州島の形成メカニズムを検討して おり, 既往の知見からも州島形成機構は定性的には解明 されているものの, 維持過程も含めて定量的な解明には まだ至っていない.

またサンゴ礁海域では, リーフ前面の急勾配斜面と水 深の浅いリーフフラットが接続された地形がよく見られ

\begin{tabular}{|c|c|c|}
\hline 1 正会員 & 博 (工) & 五洋建設(株) \\
\hline 2 正会員 & 修(工) & 五洋建設(株) \\
\hline 3 フェロー & 博(工) & 五洋建設(株) \\
\hline 4 & 理博 & $\begin{array}{l}\text { 東京大学教授 大学院理学系研究科 } \\
\text { 地球惑星科学専攻 }\end{array}$ \\
\hline 5 フェロー & 工博 & 高知工科大学 副学長 \\
\hline
\end{tabular}

る. その地形の特徴から波の分裂や再生, 海浜流の発達 など複雑な波浪場が形成され, サンゴ州島形成の定量的 な評価にはこの波浪場の評価が重要となる。例えば関本 ら（2011，2012）は，急勾配リーフ地形の波浪場評価を するために，位相平均モデルであるエネルギー平衡方程 式の改良を行い波浪場予測精度の向上を試みている.

本研究では, リーフ上の波浪場・流速場、それらに伴 う底質の移動について, 3次元水理模型実験と数值計算 により評価することにより, 急勾配リーフ上の州島形成 機構求よび維持過程の解明を試みたものである.

\section{2 平面水槽実験の概要}

実験模型は, 高橋ら（2011）, 岩塚ら（2012）と同様 に, 反射波吸収制御を有する平面水槽（幅 $30 \mathrm{~m} \times$ 奥行 $20 \mathrm{~m}$ x深さ $1.2 \mathrm{~m}$ ）に一般化したサンゴ礁州島を模擬した固定 床開放型リーフ地形（リーフ天端部：長軸 $5 \mathrm{~m} \times$ 短軸 $2 \mathrm{~m}$, 高さ $0.7 \mathrm{~m}$, 斜面部：全周 $1 / 5$ 勾配，実験縮尺 $1 / 100$ を想定 $)$ を有する急勾配リーフ模型を用いた（図-1）.

リーフ面についても, 高橋ら (2011), 岩塚ら (2012) と同様にパッチ状サンゴによる粗度を模擬しモルタル粗 仕上げとし，現地サンゴ礫を想定した中央粒径 $0.61 \mathrm{~mm} の$ 硅砂を敷き均し初期砂面を形成した.

波浪条件, リーフ上水深, 初期砂層厚の条件を変化さ せ表-1に示す計6ケースの実験を行った。なおCase-6は, 基本ケース（Case-1）と総波浪エネルギーが等しくなる ように設定した一方向不規則波の条件で, 表中には有義 波諸元を示した。実験では, 各波浪条件の規則波を15分 間作用させた後, 超音波式砂面計にて平面的な地形測量 を行った．更に波を15分ずつ作用させた30分後，45分後， 60分後の地形測量を行い，底質の移動量を評価した． 60 分後でも平衡地形に達していないと考えられるケースで 


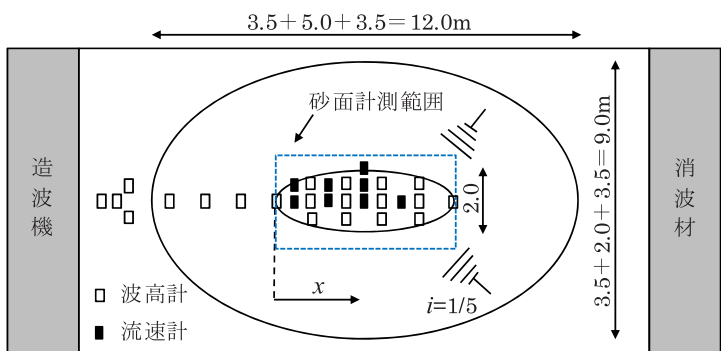

リーフ上水深 : $2.5 \mathrm{~cm} \sim 3.5 \mathrm{~cm}$

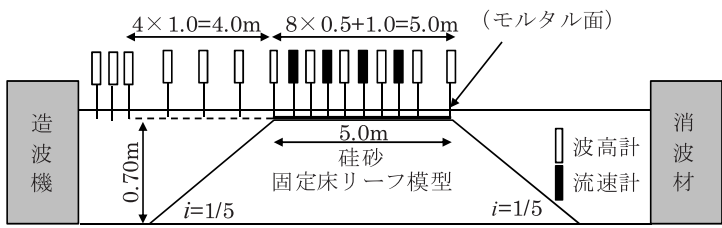

図-1 平面水槽断面とリーフ模型 (単位 : $\mathrm{m}$ )

表-1 実験条件

\begin{tabular}{c|c|c|c|c|l}
\hline Case & $\begin{array}{c}\text { 波高 } \\
(\mathrm{cm})\end{array}$ & $\begin{array}{c}\text { 周期 } \\
(\mathrm{s})\end{array}$ & $\begin{array}{c}\text { 水深 } \\
(\mathrm{cm})\end{array}$ & $\begin{array}{c}\text { 砂層厚 } \\
(\mathrm{cm})\end{array}$ & \multicolumn{1}{|c}{ 備考 } \\
\hline 1 & 1.8 & 0.8 & 2.5 & 2.0 & 基本ケース \\
\hline 2 & 1.8 & 0.8 & 3.5 & 2.0 & 水深変化 \\
\hline 3 & 3.6 & 0.8 & 2.5 & 2.0 & 波高変化 \\
\hline 4 & 1.8 & 1.2 & 2.5 & 2.0 & 周期変化 \\
\hline 5 & 1.8 & 0.8 & 2.5 & 1.5 & 砂層厚変化 \\
\hline 6 & $2.5^{\text {注1 }}$ & $0.8^{\text {注1 }}$ & 2.5 & 2.0 & 一方向不規則波 \\
\hline
\end{tabular}

注1）有義波の諸元

は最大180分後まで波を作用させた.

入射波条件やリーフ上の波や流れについては, 砂を敷 設しない固定床モルタル面の状態で, リーフ上の水位・ 流速を測定した。固定床実験では，容量式波高計を21箇 所, 電磁流速計を8箇所設置し, 水位および流速をサン プリング周波数 $20 \mathrm{~Hz} に て$ 計測した。移動床実験では，底 質の移動を妨げないようにリーフ上の計測器は全て撤去 して波を作用させた.

\section{3. 実験結果}

\section{(1) 地形変化}

写真-1は，基本ケースであるCase-1における造波開始 後15分後から180分後までの底質の移動状況を示したも のである.15分経過後には前面のリーフエッジから約 $50 \mathrm{~cm}$ 後退した位置からつながるようにリング状の堆積が 形成され，堆積頂部は静水面上に干出していた．15分後 ではリーフ中央から後方にかけての堆積はわずかであっ たが，時間が経過するとともにリング上の堆積地形が拡 大し，120分後にはほぼ完全につながったリング状の干 出地形が完成し, リーフエッジ側の堆積位置は少しずつ 後退をしたが180分経過後も維持されていた.

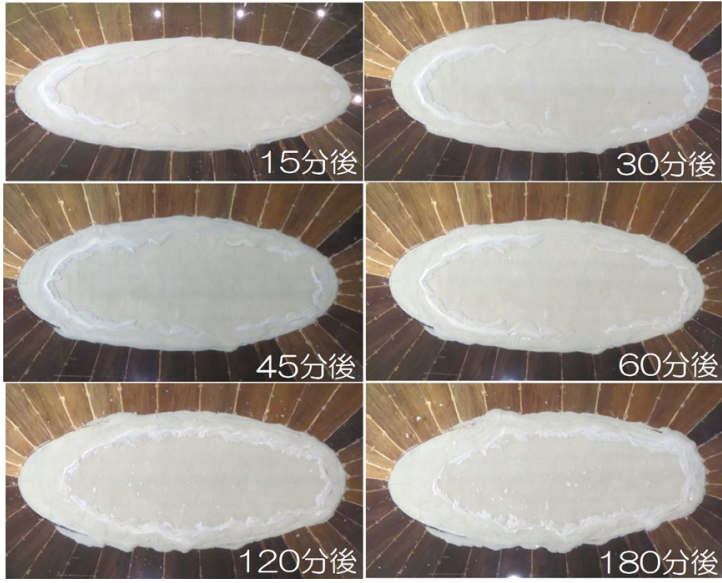

写真-1 リーフ上地形の時間変化 (Case1)

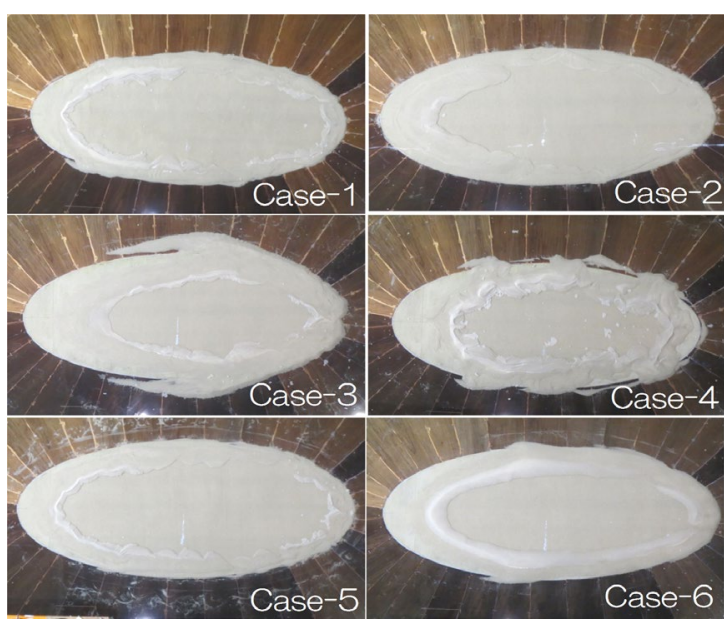

写真-2 各ケースの60分後の地形変化

岩塚ら（2012）は，台風による高波浪（実験室スケー ルで波高3.6cm, 周期1.2s）を想定した移動床実験を行い, リーフ上の底質がリーフエッジの強い砕波の影響で岸側 に輸送される過程で一時的にリーフ中央部に干出地形が 形成されたものの, 時間の経過とともにリーフ後方へ流 出していた。 しかし本条件では, 波高が小さく周期が短 いことでリーフエッジの砕波の影響が軽減し，また波長 に対してリーフサイズが相対的に大きくなったことで環 礁リーフ特有の回折波の寄与が拡大し，写真-1に示すよ うなリング状の堆積が形成されたものと考察される.

次に, 各ケースの60分後の地形を写真-2に整理した. 砂層厚が少ないC ase-5は基本ヶースと類似した地形と なっているが, 水深が深いCase-2, 波高が大きいCase-3, 周期が長いCase-4でリーフエッジ後方の堆積位置の後退 が見られ，Case-3がリーフ外への流出量とあわせ最も大 きくなっている. Case-6ではリーフエッジ後方の堆積位 置は若干後退しているものの, 全体的に堆積幅が広く安 


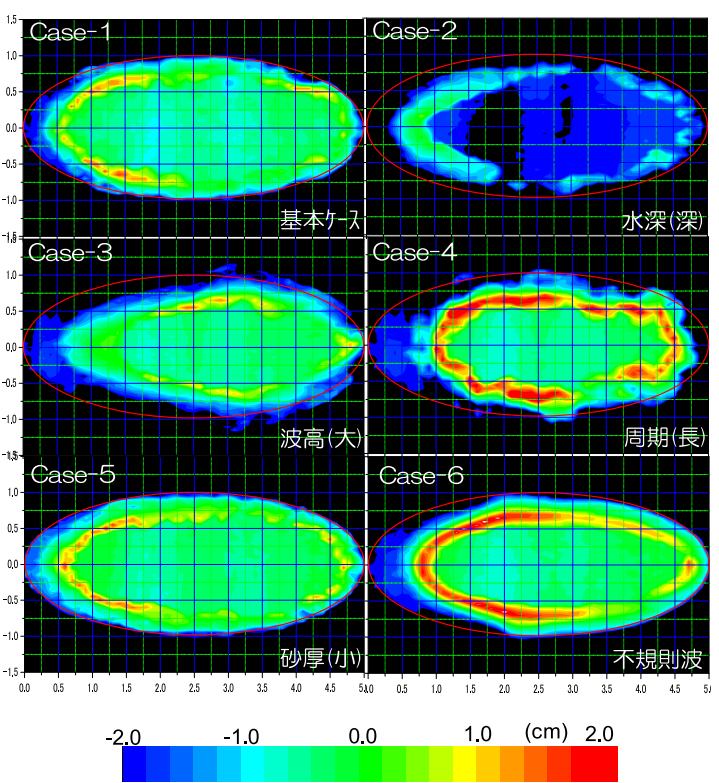

図-2 各ケースの60分後の初期砂面からの変化量

定した堆積となっている。これは高波浪による掃流効果 だけでなく，低波浪時の堆積前面側斜面を急勾配化させ る効果も影響していると考えられる.

図-2には，各ケースの60分後の底質の移動状況を初期 砂面からの変化量で示した．地形変化を比較すると，ど のケースもリーフエッジ側では侵食されているが，後退 量としては波高の大きいCase-3と周期が長いC ase-4が大 きい.なお，波高が大きいと後退とともに堆積高さも小 さくなっているが, 周期が長いと後退するものの堆積部 分の幅だけでなく堆積高さも基本ケースより大きくなっ た。また, リーフ水深が深いC ase-2のみ，堆積が見られ なくなるだけでなく, リーフエッジに加えてリーフ内で も侵食が見られる。 これはリーフ水深が梁くなることで リーフ内に存在する波浪が大きくなり，リーフ内の底質 に作用する掃流力が大きくなるためと考えられる。リー フ内の底質がリーフ外に流出しないためには、リーフ エッジで十分な砕波により波高を減衰させる必要があ る。一方向不規則波を作用させたCase-6では，波浪エネ ルギーの等しいCase-1より堆積の幅, 高さとも大きく, リング上の堆積形状が他のケースに比べて安定してい た．堆積高はC ase-4と同程度であるが，リーフ後方の地 形をみるとCase-6でも堆積は見られるがCase-4の方が顕 著である。これは，周期が長く波形勾配が小さくなるこ とで比較的リーフ後方のリーフエッジまで砕波せずに到 達していることが影響していると考えられる。

次に, リーフ長軸上の縦断地形変化について整理した. 図-3には，Case-1の15分後から120分後までの縦断地形変 化を示した。この図から，リング上の堆積が形成される
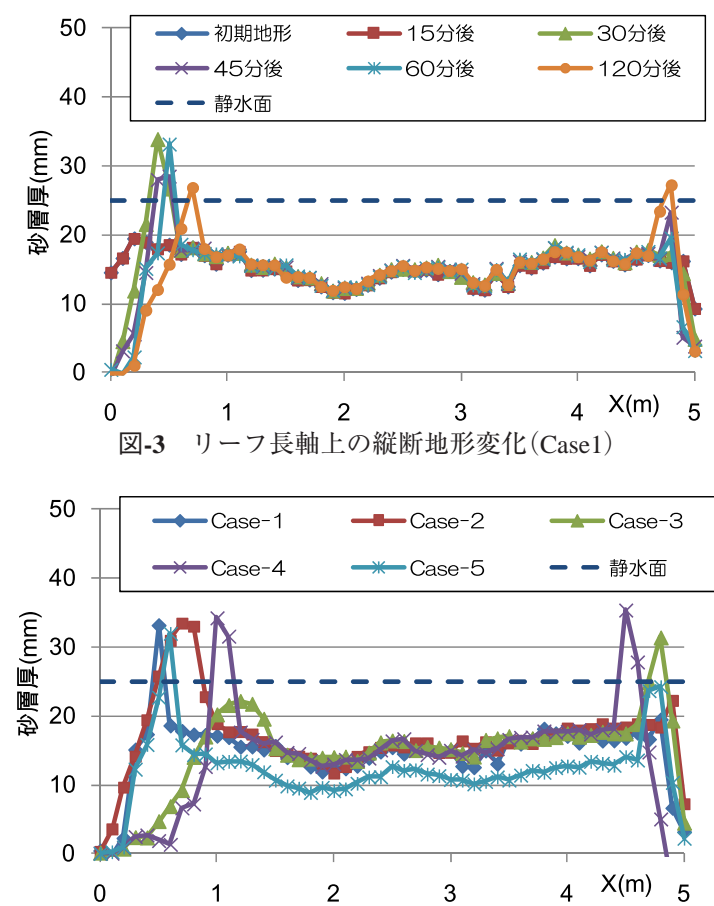

図-4 各ケースのリーフ長軸上の60分後の縦断地形

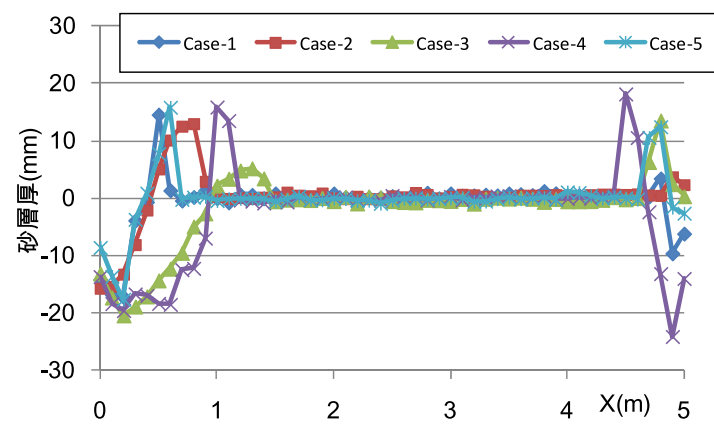

図-5 各ケースのリーフ長軸上の60分後の侵食堆積

ことで, リーフ内への波や流れの外力作用が遮蔽され， リーフ内では地形変化が生じず，リーフエッジ付近での み底質の移動が生じていることがわかる，図-4には，同 様に各ケースの60分後の縦断地形変化を示した。図中, Case-3のみ静水面が35mmの位置になる。この図より, Case-2からCase-4ではCase-1より堆積位置が後退している ことと，Case-3の堆積高さが他のケースより低いことが わかる. 初期砂面からの変化量でみると，Case-3を除き， 堆積高さはほぼ同じであるが, Case-3やCase-4ではリー フエッジ側の底質がほぼ掃流されてしまった状態であ り, 底質の供給がない限りこれ以上の堆積地形の拡大は 生じないことがわかる（図-5).

（2）リーフ上の水位・波浪・流れ

リーフ上の波・流れについて, 固定床条件で図-1に示 

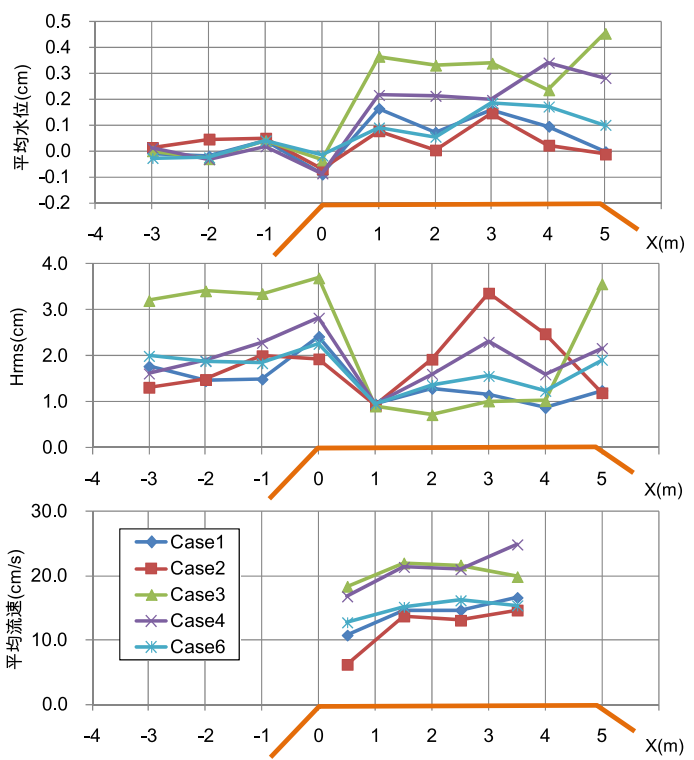

図-6 リーフ長軸上の平均水位・ $\mathrm{Hrms}$ ・平均流速

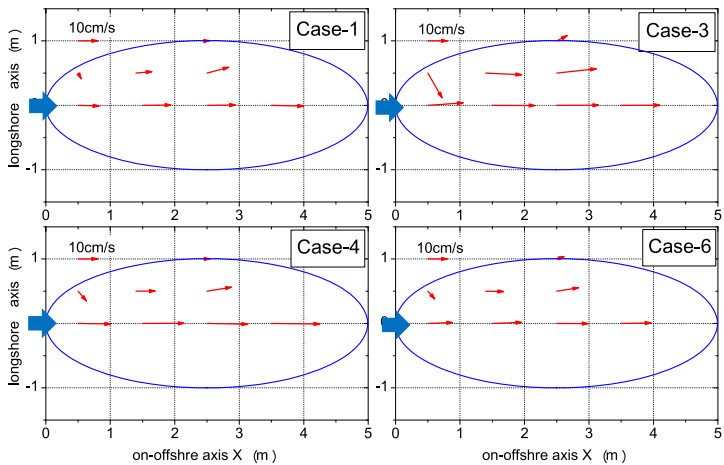

図-7 各ケースの平均流速分布

す波高計21箇所，流速計8箇所において測定を行った. なお計測は，条件がCase-1と同じになるCase-5を除いた5 ケースについて行った，図-6には，各ケースのリーフ長 軸上の平均水位, 2乗平均波高 $\mathrm{H}_{\mathrm{rms}}$, 平均流速を示した. この結果をみると, 本研究で用いた周囲を海に囲まれた 開放型リーフ地形ではリーフ上の平均水位上昇量は小さ く，今回の入射波浪条件では波高はリーフエッジから $1 \mathrm{~m}$ の位置までに十分砕波減衰していること, リーフ内の流 れは10〜20cm/s程度であったことがわかる．波高につい ては，一旦砕波により減衰した後，リーフ内またはリー フ後方で波高が増大している部分が見られる。これは, 回折波の影響でリーフ側方からの波の影響や, リーフ エッジを後方まで伝播してくる波も見られ，これらが リーフエッジで減衰した波に合成されて再生されている ものである.リーフの最後方では, 両サイドからの回折 波とリーフ内を伝播してきた波の焦点が形成され砕波す る様子も見られた．60分後の地形変化で最もリーフエッ
ジ側の堆積位置の後退が見られたC ase-4において, リン グ状の堆積位置がリーフエッジからおおよそ1mである. リーフ内の平均流速分布（図-7）をみると, 固定床の条 件であるが, リーフエッジ付近では砕波によるリーフ内 に向かう強い流れが見られるが，リーフ内では基本的に リーフ後方に向かう流れが卓越している，移動床実験で は流速を測定していないが, リーフエッジ後方に堆積が 形成される遮蔽効果によりリーフ内の流れが減衰すると 考えられる.このことからリーフ内の堆積は, リーフ エッジに扔ける砕波による波高減衰と, リーフサイズと 波長との相対関係が影響し，堆積地形形成によるリーフ 内への波・流れが遮蔽される効果とあわせ干出地形が形 成・維持されたものと考察される.

\section{3. 位相平均型波浪変形モデルによる再現計算}

急勾配リーフ地形の外力場は, 砕波を含む非常に非線 形性の強い現象で, 高波浪時にはリーフエッジの干出も あり，ブシネスク方程式に代表される高精度時間領域モ デルでも適用が難しいと考えられる。特にリーフ岸側の 回折領域の波浪変形の評価に抒いては, 既往の波浪変形 モデルでは評価が難しいと思われる。

本研究では, 関本ら（2012）により2次元断面急勾配 リーフ地形に扔ける波浪変形への適用性が確認された, エネルギー平衡方程式にサーフェスローラーの砕波減衰 を考虑した田島ら（2005）の改良モデルを用いて再現計 算を試みた。リーフ内の流れについては，計算された波 高分布から海浜流として評価した.

なお, 関本ら（2012）の検討でも, 潮位が低く, リー フエッジでバックウォッシュが生じるようなケースでは まだ課題が残されている。また田島ら（2005）のモデル も基礎方程式はエネルギー平衡方程式であるのでリーフ 後方の回折波の影響は評価が難しい。ここでは，底質移
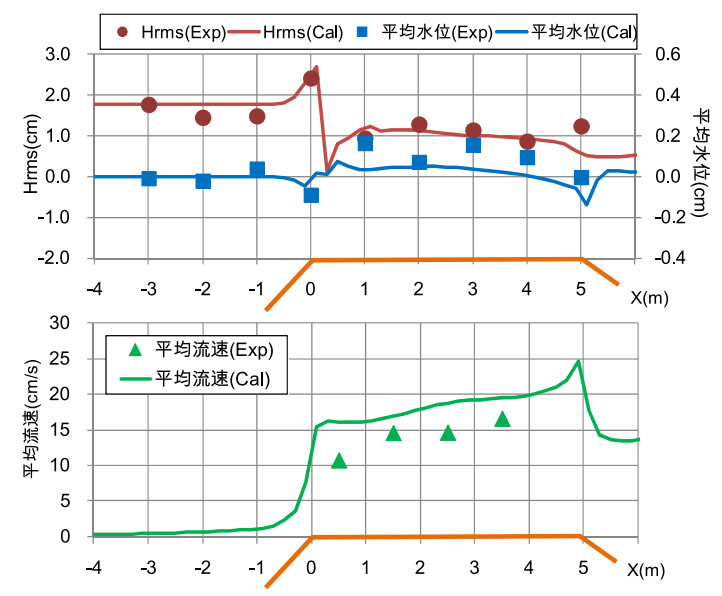

図-8 リーフ長軸上の平均水位・ $\mathrm{Hrms}$ ・平均流速の実験結果 と計算結果の比較 (Case1) 

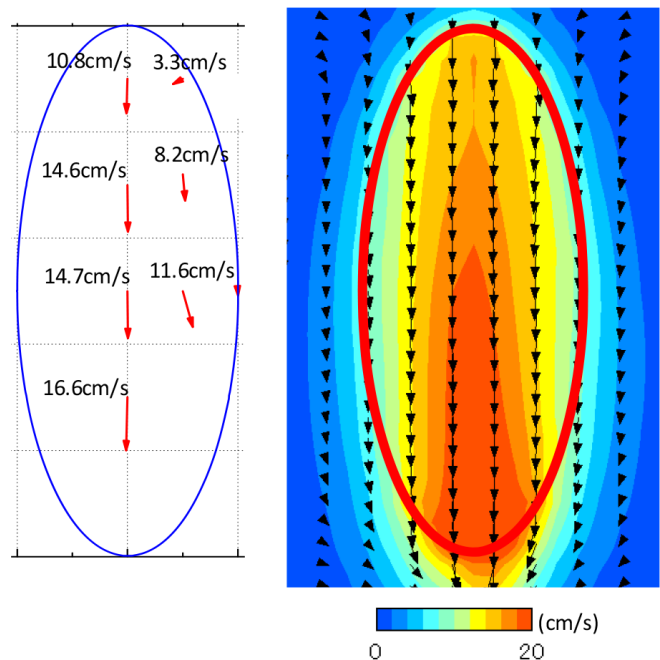

図-9 平均流速分布の実験結果と計算結果の比較(Case-1)

動が卓越する前面側のリーフエッジ付近の外力場を評価 することを念頭に検討を行った。

図-8にC ase-1のリーフ長軸上の平均水位, $\mathrm{H}_{\mathrm{rms}}$, 平均流 速の実験結果（固定床）と計算結果を比較した。この結 果, リーフ内の平均水位やリーフエッジでの砕波による 波浪減衰については, リーフ後方の回折波が支配的とな る領域の波高増大を除けば概ね再現できている．また平 均流速については，計算の方がやや過大評価ではあるこ とや，実験で生じているリーフエッジ付近の砕波による 強い岸向き流速が再現できないこと等の課題はあるもの の, リーフ後方に向けて平均流速が増大する様子やリー フ長軸から側方に向かい流速が減衰する点等が表せてい ることがわかる（図-9)，回折域の波高評価が課題である が, 今回の方法でリーフエッジ付近の底質移動の外力場 の概略の傾向評価は可能であると考えられる.

\section{6. まとめ}

サンゴ礁州島の形成および維持機構について，外力場 として重要となるリーフ上の波浪場・流速場，それらに 伴う底質の移動について3次元水理模型実験により検討 を行った．また外力場についてエネルギー平衡方程式を 基本とする田島ら（2005）の改良モデルを適用した結果, 以下の結論が得られた。

（1）開放型急勾配リーフ上で, リーフエッジの砕波によ り静水面から干出する環礁州島に見られるようなリ ング状の堆積地形が形成され, その遮蔽効果も伴い 干出地形が維持される現象を再現した.

（2）リーフ上のサンゴ礁州島の形成・維持過程には,
リーフエッジにおける砕波による波高減衰とリーフ サイズと波長との相対関係抢よび堆積地形形成によ るリーフ内への波・流れの遮蔽効果が重要である.

（3）急勾配リーフ地形への適用を念頭に改良したエネル ギー平衡方程式により，回折波の影響が支配的な リーフ後方を除き, リーフエッジの砕波からリーフ 内への波浪減衰および流れを概ね再現できた。

今後は, 数值モデルの精度向上と併せ, 地形変化モデ ルの構築に取り組む予定である。

謝辞: 本研究は建設技術研究開発助成制度 (国土交通 省), および東京大学海洋アライアンスイニシャティブ （日本財団）の協力を得ました。ここに記して関係各位 に謝意を表します。

\section{参 考 文 献}

岩塚雄大 ·片山裕之 · 関本恒浩 - 青木健次 - 茅根 創 - 磯部 雅彦 (2012）：急勾配リーフ上のサンゴ礁州島形成メカニ ズムに関する研究, 土木学会論文集B2 (海岸工学), Vol. 68, No. 2, pp.I_476-I_480.

宇多高明 (1988)：壬ルディブに打ける高潮災害の現地調查, 第35回海岸工学講演会論文集, 第35卷, pp. 212-216.

宇多高明・谷本修志・坂野 章・高木利光 (1990) : リーフ上 およびリーフギャップ周辺に扔けるサンゴ片の移動機構, 海岸工学論文集, 第37巻, pp. 215-219.

宇多高明・小菅 晋・伊藤弘之・山崎順一 (1992)：サンゴ洲 島の形成・消失機構に関する研究, 海岸工学論文集, 第 39卷, pp. $376-380$.

宇多高明・小菅 晋・鈴木將之 (1995)：サンゴ洲島の形成機 構に関する実験的研究, 海洋開発論文集, Vol. 11, pp. 73-78.

鈴木拓也（2013）：サンゴ礁州島形成に抢ける外力条件の評価, 東京大学大学院理学系研究科修士論文.

鈴木拓也·茅根 創・岩塚雄大 - 片山裕之 - 関本恒浩 - 磯部 雅彦 (2013) : サンゴ礁州島の地形変化メカニズムに関す る研究, 土木学会論文集B3 (海洋開発), Vol. 69, No. 2, pp.I 838-I 843.

関本恒浩・中鳲さやか・片山裕之・高橋研也 (2011)：急勾配 リーフ地形における砕波現象と実務に向けた位相平均型 波浪変形モデル, 土木学会論文集B2 (海岸工学), Vol. 67, No.2, pp.II11-I_15.

関本恒浩・中嶋さやか・片山裕之・高橋研也（2012）：急勾配 を有するリーフ地形上の波浪エネルギーによる波浪場評 価に関する研究, 土木学会論文集B2 (海岸工学), Vol. 68, No.2, pp.I_51-I_55.

高橋研也 - 片山裕之 ·関本恒浩 - 青木健次 - 茅根 創 - 磯部 雅彦（2011）：サンゴ礁州島形成に及ぼす波・流れ・砂供 給の影響に関する基礎的研究, 土木学会論文集B2（海岸 工学), Vol.67, No.2, pp.I_636-I_640.

田島芳満・M adsen, O. S. (2005)：Surface Rollerによる影響を 考虑した戻り流れの鉛直分布のモデリング，土木学会論 文集, No. 803/II-73, pp. 133-144. 